\title{
Adipose Tissue: Autologous Filler and Multipotent Stem Cell Source
} Ziyad Alharbi*, Norbert Pallua

Department of Plastic and Hand Surgery, Burn Center, RWTH Aachen University, Pauwelsstr 30, 52074 Aachen, Germany

\begin{abstract}
Autologous fat grafting is commonly used as a filler material to correct soft tissue defects of various sizes. Its applications range from reconstructive treatment as well as for cosmetic enhancements, such as breast augmentation, hand and face rejuvenation. Recently, deep investigations were just concentrating on the biological and physiological aspect of fat tissue which has driven the line from being just an autologous material for filling to a multipotent stem cell source for multiple regenerative purposes. After their isolation from harvested fat, adipose derived stem/stromal cells (ASCs) or multipotent stromal-derived cells obtained from Stromal Vascular Fraction (SVF), can give wide possibilities in regenerative medicine approach. They can differentiate not only to adipogenic lineage but also to osteogenic, chondrogenic, myogenic and neurogenic lineage in vitro. An attractive advantage of these adult stem cells is that fat graft provides an easily obtainable source of ASCs. Furthermore, harvested fat graft contains significant quantities of growth factors leading to an interesting interaction that can result in better healing and angeogenesis process. Apart from all proven basic scientific evidence, we are at the beginning of a new era of stem cell therapy. Nevertheless, their viability after isolation should be deeply identified as many gaps exist in terms of isolation process with specific markers, proliferation and differentiation protocols delivery systems, culturing process and therapeutic applications of stromal vascular fraction based cells or ASCs. Further in vitro and in vivo investigation should enhance our knowledge toward ASCs and their interactions with other cells, autologous materials, growth factors, cytokines, and tissue engineered products especially during tissue repair and regeneration.
\end{abstract}

\section{Fat tissue and autologous fat transfer}

Adipose tissue is basically derived from lipoblasts or the so called preadipocytes; immature precursor cells that differentiate into mature adipocytes [1]. Adipose tissue in general play an important role in energy storing, temperature regulation, endocrine functions moderation, and considered to be a powerful autologous filler and recently as a stem cell source. Fat grafting or autologous fat transfer is a method whereby fat is removed from one area of the body and reinserted into the desired recipient location. Autologous fat grafting is commonly used as a filler material to correct soft tissue defects of various sizes. Its applications range from reconstructive treatments as well as for cosmetic enhancements, such as breast augmentation, hand and face rejuvenation.

Although soft tissue augmentation by fat grafting with adipose tissue derived from liposuction procedures has shown promising results with less invasive techniques, variation in long-term outcome in terms of loss of transplanted volume has been reported [2,3]. One reason for the decrease in volume is insufficient blood supply after transplantation. Therefore, neovascularization process is crucial to the survival rate of adipocytes, which are subjected to apoptosis and necrosis if not supported by a network of capillary vessels [4]. Studies have shown that hypoxia and the poor nutritional supply to the transplanted fat tissue play an important role in this point [5].

Thus, deep investigations have been performed, concentrating on the biological and physiological aspect of fat tissue which has driven the line from being just an autologous material for filling to a multipotent stem cell source for multiple regenerative purposes.

\section{Fat tissue as a stem cell source}

Adipose tissue contains a large number of multipotent cells, which is an essential prerequisite for stem-cell-based therapies. It has been described that stem and progenitor cells in the uncultured stromal vascular fraction (SVF) from adipose tissue usually amount to up to $3 \%$ of the whole cells, and this is 2,500-fold more than the frequency of stem cells in bone marrow [6]. Furthermore, Pallua et al. [7] in 2009 have found significant quantities of basic fibroblast growth factor (bFGF), insulin-like growth factor (IGF), vascular endothelial growth factor (VEGF), and platelet-derived growth factor (PDGF) in freshly harvested lipoaspirate after centrifugation and incubation [7].
The term 'Stromal Vascular Fraction' (SVF) is commonly used in the literature and refers to the cellular pellet without fat cells (mature adipocytes). It can be obtained, under tight condition, through isolation process containing of multiple cells such as pre-adipocytes, endothelial cells, smooth muscle cells, pericytes, and fibroblasts [8]. Thus, SVF provide main access to obtain stem cells with an easy approach of isolation without invasive procedures.

\section{Adipose Tissue-Derived Stem/Stromal Cells (ASCs)}

In fact, autologous fat grafting has been well established, but less is known about therapy with adipose derived stem/stromal cells (ASCs) or multipotent stromal-derived cells. ASCs are self renew cells of mesenchymal origin. They can differentiate not only to adipogenic lineage but also to osteogenic, chondrogenic, myogenic and neurogenic lineage in vitro [9]. They can be obtained easily from the liposuction procedure and then tighter conditions take place for the isolation process. An attractive advantage of these adult stem cells is that lipoaspirate provides an easily obtainable source of ASCs.

Gimble [10] suggested that regenerative stem cells should be found in abundant quantity, harvested with minimally invasive procedure, can differentiate to multiple cell lineage, can be transplanted to autologous or allogenic host and can be manufactured with high practice guidelines [10]. These requirements could be seen in the adipose tissue as stem cell source [9].

*Corresponding author: Ziyad Alharbi, M.D, Department of Plastic and Hand Surgery - Burn Center, Medical Faculty, RWTH Aachen University, Pauwelsst 30, 52074 Aachen, Germany, Tel: +49-241-80-0; Fax: +49-241-80-82634; E-mail: zalharbi@ukaaachen.de

Received November 11, 2012; Accepted November 20, 2012; Published November 22, 2012

Citation: Alharbi Z, Pallua N (2012) Adipose Tissue: Autologous Filler and Multipoten Stem Cell Source. Anaplastology 1:e107. doi: 10.4172/2161-1173.1000e107

Copyright: (c) 2012 Alharbi Z. This is an open-access article distributed under the terms of the Creative Commons Attribution License, which permits unrestricted use, distribution, and reproduction in any medium, provided the original author and source are credited. 
Citation: Alharbi Z, Pallua N (2012) Adipose Tissue: Autologous Filler and Multipotent Stem Cell Source. Anaplastology 1:e107. doi: 10.4172/2161$1173.1000 \mathrm{e} 107$

\section{Tissue Engineering Approach, Right Now Limitations and Future Possible Applications of ASCs}

Nowadays, state of the art has been clearly taken to the possible clinical use of the ASCs after their isolation. Such approach is nowadays affected by several factors including the cost effectiveness and the legal framework. ASCs have shown a major role in promoting wound healing. ASCs secret almost all growth factors that take part in normal wound healing condition including basic fibroblast growth factor (bFGF), insulin-like growth factor (IGF), vascular endothelial growth factor (VEGF), and platelet-derived growth factor (PDGF) [7]. Furthermore, It has been reported that ASCs promote vessel density, granulation process and collagen thickness [11]. Adipose tissue is abundant source of multipotent stem cells that can be used for different linage approach and specifically for adipose tissue reconstruction together with tissue engineered scaffolds such as collagen based scaffolds which was seen as a good carrier for adipose tissue engineering.

Apart from all the proven basic scientific evidence, we are at the beginning of a new era of stem cell therapy. ASCs can be one of the most powerful adult stem cells and may take an important position in the field of tissue repair and regeneration for many systems. Nevertheless, their viability after isolation should be deeply identified as many gaps exist in terms of isolation process with specific markers, proliferation and differentiation protocols, delivery systems, culturing process and their therapeutic applications [12]. Further in-vitro and in-vivo investigation should enhance our knowledge toward ASCs and their interactions with other cells, autologous materials, growth factors, cytokines, and tissue engineered products especially during tissue repair and regeneration.

\section{References}

1. Tanti JF, Grillo S, Grémeaux T, Coffer PJ, Van Obberghen E, et al. (1997) Potential role of protein kinase $B$ in glucose transporter 4 translocation in adipocytes. Endocrinology 138: 2005-2010.

2. Coleman SR (2001) Structural fat grafts: the ideal filler? Clin Plast Surg 28 111-119.

3. Bucky LP, Percec I (2008) The science of autologous fat grafting: views on current and future approaches to neoadipogenesis. Aesthet Surg J 28: 313321.

4. Crandall DL, Hausman GJ, Kral JG (1997) A review of the microcirculation of adipose tissue: anatomic, metabolic, and angiogenic perspectives. Microcirculation 4: 211-232.

5. Carpaneda CA, Ribeiro MT (1994) Percentage of graft viability versus injected volume in adipose autotransplants. Aesthetic Plast Surg 18: 17-19.

6. Fraser JK, Zhu M, Wulur I, Alfonso Z (2008) Adipose-derived stem cells Methods Mol Biol 449: 59-67.

7. Pallua N, Pulsfort AK, Suschek C, Wolter TP (2009) Content of the growth factors bFGF, IGF-1, VEGF, and PDGF-BB in freshly harvested lipoaspirate after centrifugation and incubation. Plast Reconstr Surg 123: 826-833.

8. Tholpady SS, Llull R, Ogle RC, Rubin JP, Futrell JW, et al. (2006) Adipose tissue: stem cells and beyond. Clin Plast Surg 33: 55-62.

9. Mizuno H (2009) Adipose-derived stem cells for tissue repair and regeneration: ten years of research and a literature review. J Nippon Med Sch 76: 56-66.

10. Gimble JM (2003) Adipose tissue-derived therapeutics. Expert Opin Biol Ther 3: 705-713.

11. Ebrahimian TG, Pouzoulet F, Squiban C, Buard V, André M, et al. (2009) Cell therapy based on adipose tissue-derived stromal cells promotes physiological and pathological wound healing. Arterioscler Thromb Vasc Biol 29: 503-510.

12. Sensebé L, Bourin P (2008) Producing MSC according GMP: process and controls. Biomed Mater Eng 18: 173-177. 